\author{
Stawomir Juszczyk \\ Warsaw University of Life Sciences
}

Karol Gancewski

mBank

\title{
OFFER OF PRIVATE BANKING OF KEY BANKS IN POLAND - STATE AND PERSPECTIVES
}

The aim of the research was to identify and assess the changes of private banking in Poland. The research determined among others that the financial products with the lowest risk are currently the most popular among private banking clients of the surveyed banks. It was also determined that the most popular service in the next 2 years will probably be investment advice. Non-banking services such as legal and tax consultancy, educational consulting or concierge services will be an addition to the private banking in Poland.

Key words: affluence, private banking, wealth management, HNWI group

\section{Introduction}

Private banking is one of the fastest-growing areas of commercial banks in Poland. The growing interest in the private banking segment results from the constantly growing number of affluent people and the increase in the value of their assets. The scale of operations of commercial banks in Poland in the field of private banking is growing not only due to quantitative changes in this segment, but also due to qualitative changes that also concern the scope of services addressed to wealthier Poles and changes in their provision which resulting from new legal requirements ( including the implementation of the MIFID II Directive).

The number of clients in the private banking segment and the value of the capital employed by them is important for the functioning of the international financial market as well. Banking for affluent people is inextricably linked to the allocation of cash through financial instruments to the global economy. For these reasons, there is strong competition between banks providing private banking services. International and investment banks, including JP Morgan, Chase, UBS, HSBC, Merrill Lynch and specialized Swiss banks, are among the most important international financial institutions offering banking for wealthy clients.

Private banking in Poland is developing parallel to the growth of the number of affluent people in Poland and is one of the more advanced forms of activity in the context of retail banking. As the first private banking offer in Poland in 1993 was introduced by Bank Handlowy (currently Citi Handlowy). It can be seen that the domestic segment is trying to build its own identity, but in part it is based on more developed markets in this area in the world.

It is worth adding that estimating the number of affluent individual customers in the world, we use the size of the group referred to as High-Net-Worth Individuals (HNWI) together with the investment assets accumulated by them. In order for a person to be 
included in this group, he must have assets of more than USD 1 million, excluding the property of the main residence, collectors' items or consumer goods. What's more, each of the financial institutions serving individual clients determines independently the thresholds of financial assets that a bank client must have. The presented threshold (USD 1 million) can be treated as a contractual value for the international private banking market. In 2016, in world the number of people included in the HNWI group was 16.5 million, and the value of the funds collected by it amounted to 63.5 trillion USD.

Table 1. HNWI Group at the end of 2016

\begin{tabular}{|c|c|c|}
\hline $\begin{array}{c}\text { Region } \\
\text { Region }\end{array}$ & $\begin{array}{c}\text { Number (in millions) } \\
\text { Liczebność (w mln) }\end{array}$ & $\begin{array}{c}\text { Assets (in trillions of USD) } \\
\text { Majątek (w bln USD) }\end{array}$ \\
\hline $\begin{array}{c}\text { Africa } \\
\text { Afryka }\end{array}$ & 0,2 & 1,5 \\
\hline $\begin{array}{c}\text { Latin America } \\
\text { Ameryka Lacińska }\end{array}$ & 0,6 & 2,0 \\
\hline $\begin{array}{c}\text { Middle East } \\
\text { Bliski Wschód }\end{array}$ & 0,6 & 2,4 \\
\hline $\begin{array}{c}\text { Europe } \\
\text { Europa }\end{array}$ & 4,5 & 14,7 \\
\hline $\begin{array}{c}\text { North America } \\
\text { Ameryka Północna }\end{array}$ & 5,2 & 18,0 \\
\hline $\begin{array}{c}\text { Asia and the Pacific region } \\
\text { Azja i region Pacyfiku }\end{array}$ & 5,5 & 18,8 \\
\hline $\begin{array}{c}\text { Altogether } \\
\text { Ogółem }\end{array}$ & 16,5 & 63,5 \\
\hline
\end{tabular}

Source: World Wealth Report 2017, Capgemini, 2017, p.7.

The key regions for private banking are Asia and the Pacific region, North America and Europe. It is in these regions that more than $92 \%$ of HNWI customers and approximately $81 \%$ of the global value of financial assets of this group are concentrated. Of these three regions, the leader in terms of the number of affluent clients is Asia and the Pacific region, where in 2016 there were 5.5 million HNWI customers and whose assets totalled 18.8 trillion USD. In terms of the number of affluent clients, the region is dominated by Australia, Japan, Singapore and Hong Kong. Another region important for the analysed issue is North America with 5.2 million people included in the HNWI group. The majority of affluent people live in the United States and Canada. An important region that plays a significant role in the HNWI market is Europe. There are 5.2 million affluent people living on this continent - with a total assets of 14.7 trillion USD. In Europe, the leaders in this field are Great Britain, Germany, France and Switzerland. Since 2010, the largest increase in the number of affluent people has been observed in Asia and the Pacific region, where the HNWI group increased by 2.2 million people. In 2015, Asia and the Pacific region overtook North America and became the leader of the HNWI market.

In literature, we find many definitions of private banking. According to Leszek Dziawgo, private banking in functional terms is a set of appropriate activities using the right products and services addressed to the right customer, no matter what 
institution offers it ${ }^{1}$. In addition to the functional approach, there is also an institutional approach in which emphasis is placed on the entity offering private banking, i.e. a banking institution. It may be a bank specialized in private banking as well as branches of universal or investment banks. In accordance with the functional and institutional approach, private banking is a series of banking services, such as asset management or investment consultancy offered to affluent clients. By the concept of a wealthy client we mean a person who meets the eligibility criteria set by banking institutions that provide private banking. It is worth adding that, although it is not frequent, the criteria for choosing a wealthy client do not have to be its assets. This is the case for people with high social prestige who, in return for using private banking services, popularize the institution and create its image.

The basic offer of private banking is related to the broadly understood financial market. In particular, it concerns four segments, such as: the money market, the capital market, the currency market and the derivatives market. As part of operations on given markets, the private banking offer can be divided into basic and specialist. The basic one is widely available for affluent clients and there is also no major difference between offers of this type proposed by individual banking institutions that provide private banking. It should be emphasized that the specialist offer in Poland includes services or products less frequently found on the market, such as hedge funds.

Private banking in Poland is not limited only to the sphere of the financial market, but goes far beyond it. This applies to services related to, for example, legal advice, sports, tourism or collections of works of art. In the case of works of art, the client receives help from the bank in terms of their acquisition, valuation or confirmation of authenticity. It may also be represented by a bank employee at auctions. It is worth noting that collecting does not have to be related only to works of art; its object may be for example - wine ${ }^{2}$.

These days, the notions of "private banking" and "wealth management" are incorrectly equated, and banking institutions often use these terms on the basis of marketing aspects. In the case of the term "private banking", the banking nature of the service provided is underlined. It is a mature concept that clearly indicates the pedigree of serving affluent clients. The concept of "wealth management" shows that currently provided banking services do not have to dominate in the broadly understood wealth management of wealthy people. However, as mentioned above, private banking offer can also, to a large extent, go beyond standard banking services.

The proper reason why we should not equate these two concepts is the fact that wealthy people are not serviced solely by banking institutions, and using the term "private banking" in this case is a mistake. Another reason is the issue of customer service. When it comes to wealth management, the service may concern both natural persons and legal persons, while private banking is reserved exclusively for affluent individual clients ${ }^{3}$.

\footnotetext{
${ }^{1}$ L. Dziawgo, Private banking: bankowość dla zamożnych klientów, Wolters Kluwer, Kraków 2006, s. 13.

${ }^{2}$ J. Mazurek, Kultura, sztuka, wino i klimat, http://www.idg.pl/artykuly/55277.htm, data dostępu: [20.03.2018] ${ }^{3}$ Ibidem.
} 


\section{Methodical issues and research results}

The aim of the research was to identify and assess the changes of private banking in Poland. The research covered 5 leading commercial banks in Poland providing services for wealthy individual clients. The banks were selected based on the sum of assets at the end of 2017. The scope of research in the bigest banks in Poland concerned qualitative changes that took place in the last 2-3 years and concerned private banking.

Table 2. Assets at the end of 2017 [mln EUR]

\begin{tabular}{|c|c|}
\hline Banks & Assets \\
Banki & Aktywa \\
\hline PKO Bank Polski & 71113 \\
\hline Bank Polska Kasa Opieki & 44420 \\
\hline Bank Zachodni WBK & 36567 \\
\hline mBank & 31477 \\
\hline ING Bank Śląski & 30181 \\
\hline
\end{tabular}

Source: Report on the condition of banks in 2017, Office of the Polish Financial Supervision Authority, Warsaw 2018, p. 76.

The basic source of information was data which was obtained on a precedent basis from 5 leading commercial banks in Poland. The method of interviewing employees of the private banking segment was also complementary. This questionnaire included questions about the experience of advisors with the most affluent clients and quality changes in service offer in 2015-2017.

Table 3. Capital requirements of the private banking offer in the surveyed banks [as at 06/30/2018]

\begin{tabular}{|c|c|c|}
\hline $\begin{array}{l}\text { Banks } \\
\text { Banki }\end{array}$ & $\begin{array}{l}\text { Offers } \\
\text { Oferty }\end{array}$ & $\begin{array}{l}\text { Capital requirements } \\
\text { Wymogi kapitałowe }\end{array}$ \\
\hline PKO Bank Polski & Private banking & $\begin{array}{l}\text { Assets in the bank: } 1000000 \mathrm{zl} \\
\text { Aktywa w banku: } 1000000 \mathrm{zl}\end{array}$ \\
\hline $\begin{array}{l}\text { Bank Polska Kasa } \\
\text { Opieki }\end{array}$ & Pekao Private Banking & $\begin{array}{l}\text { Assets in the bank: } 1000000 \mathrm{zl} \\
\text { Aktywa w banku: } 1000000 \mathrm{zt}\end{array}$ \\
\hline Bank Zachodni WBK & BZ WBK Private Banking & $\begin{array}{l}\text { For external customers, the assets in the bank: } \\
\text { PLN 1,000,000 } \\
\text { For internal clients, assets in the bank: PLN } \\
3,000,000 \\
\text { Dla klientów zewnętrznych aktywa w banku: } \\
1000000 \mathrm{zł} \\
\text { Dla klientów wewnętrznych aktywa w banku: } \\
3000000 \mathrm{zł}\end{array}$ \\
\hline mBank & mBank Private Banking & $\begin{array}{l}\text { Assets in the bank: } 1000000 \mathrm{zl} \\
\text { Aktywa w banku: } 1000000 \mathrm{zl}\end{array}$ \\
\hline \multirow{2}{*}{ ING Bank Śląski } & ING Private Banking & $\begin{array}{l}\text { Assets in the bank: PLN } 1,000,000 \text { or one-time } \\
\text { investment min. PLN } 200,000 \\
\text { Aktywa w banku: } 1000000 \mathrm{zł} \text { lub jednorazowa } \\
\text { inwestycja min. } 200000 \mathrm{zł}\end{array}$ \\
\hline & ING Wealth Management & $\begin{array}{l}\text { Assets in the bank: PLN } 4000000 \text { or one-time } \\
\text { investment min. PLN 1,000,000 } \\
\text { Aktywa w banku: } 4000000 \mathrm{zł} \mathrm{lub} \mathrm{jednorazowa} \\
\text { inwestycja min. } 1000000 \mathrm{zł}\end{array}$ \\
\hline
\end{tabular}

Source: Own research. 
Individual customers who want to use private banking offers must meet the capital requirements set by the bank. What is important they are not standardized for the entire private banking segment in Poland because each of the financial institutions determines them according to their own method. Characteristically the service of private banking clients is associated with numerous privileges, more favorable offers and a dedicated advisor. Table 3 presents the minimum capital requirements that must be met by a private banking client in the analyzed banks.

The amount that most often appears in Table 3 is PLN 1 million. The owners at least this amount can use private banking services in all analyzed commercial banks in Poland. The exception is Bank Zachodni WBK, where capital requirements depend on the client's cooperation with the bank. For external customers who do not have an account in BZ WBK, this value is further PLN 1,000,000. However, customers who previously collaborated with the bank must accumulate a minimum of PLN 3,000,000 in order to be able to use private banking services. Quite another story is ING Bank Śląski. This bank are two parts for affluent clients, ING Private Banking and ING Wealth Management. Customers with at least PLN 4,000,000 of assets or making a one-time investment for a minimum of PLN 1,000,000 can use ING Wealth Management services. In comparison with ING Private Banking clients, they can count on even more sophisticated and varied service of Wealth Management and especially dedicated offer.

The offer of private banking in the surveyed commercial banks is wide, consisting of both banking and non-bank services. In addition, these operations do not have to take place exclusively on the financial market, because as part of the private banking offer, the client can invest his money, for example, in works of art or precious metals. In the context of investing financial surpluses, PKO BP has prepared a wide range of deposit products for its clients. Interest rates are set individually with private banking clients. PKO BP offers a wide range of securities listed on the Warsaw Stock Exchange and customers have for their disposal domestic and foreign funds, closed-end investment funds and structured products. Also, the prices of credit products are tailored to the customer, and the requests considered as a priority (faster than for the retail segment). As part of private banking, the clients of the PKO BP have access to the Concierge service, for example they can order hotel, restaurant or purchase of theater tickets. The Priority Pass package provides access to many prestigious rooms at airports in Poland and abroad $^{4}$.

As part of the investment for its clients from the private banking segment, Bank Pekao S.A. offers term deposits opened for a period of 2 to 365 days (available in CHF, USD, EUR and GBP). As in the case of PKO BP, Pekao S.A. provides the opportunity to negotiate preferential term deposit conditions. Another form of investment can be investing money in structured products, such as: Structured deposit - "Index for Profit", Structured Certificates without capital protection - "Convertible Reverse into shares" and "Express Plus for shares".

The client may also invest his money through dual currency investments, where the profit depends on the exchange rate of the basic currency and the alternative currency. The bank's offer also includes more standard investment products, such as: open

${ }^{4}$ Offer, Oferta, http://www.bankowoscprywatna.pkobp.pl/oferta/, data dostępu: [22.06.2018]. 
investment funds, closed-end investment funds, state treasury bonds and corporate bonds. What's more as part of private banking the client is entitled to a personal account - Eurokonto Prestigious. In terms of the account, the customer can count on unique Assistance insurance, including Concierge services. The client of the Pekao private banking segment is entitled to prestigious debit and credit cards. These are World Elite Debit MasterCard and Maestro Private Banking Debit Cards as well as credit cards such as Pekao VISA Infinite, Pekao World Elite MasterCard, Pekao VISA Platinum and Peako MasterCard Platinum.

Researches has shown that BZ WBK offers its clients the opportunity to protect capital through: savings accounts, term deposits, structured deposits and investment gold BZ WBK-Mennica. In mid-2018, this bank maintained subscriptions for three investment deposits. These were structured deposits:

- EUR / PLN (interest rate dependent on the EUR / PLN exchange rate),

- Double Chance (interest rate dependent on the Euro Stoxx 50® index),

- USD Stable pair (interest rate depending on the USD / PLN exchange rate).

What's more this bank give the possibility to construct structured products at the individual customer's request. Private placement is possible for customers with not less than PLN 4,000,000 of assets in that Bank. In terms of available financial solutions BZ WBK offers open investment funds in order to build capital by the client. In the product offer the bank divides open funds to: conservative, stable, dynamic and joint-stock. What's more in order to multiply funds, the Bank also offers bond products, such as corporate bonds, state treasury bonds, and ETF - Exchange Traded Found Bonds. As alternative investments BZ WBK has derivatives in its offer for wealthy clients, among others futures, options and currency options. As part of non-banking activities for affluent BZ WBK provides tax advisory services which is the responsibility of the specialized consulting company Cirdo Taxand. In terms of cooperation the client is provided with advice and services related among other the asset succession. Platinuma and gold cards available as part of the private banking segment enable the use of insurance services and the Concierge service. This service provides clients with assistance in organizing travel or buying tickets for cultural events. As part of the Priority Pass customers have access to over 700 VIP airport points in over 400 cities all over the world.

What's more this bank give the possibility to construct structured products at the individual customer's request. Private placement is possible for customers with not less than PLN 4,000,000 of assets in that Bank. In terms of available financial solutions BZ WBK offers open investment funds in order to build capital by the client. In the product offer the bank divides open funds to: conservative, stable, dynamic and joint-stock. What's more in order to multiply funds, the Bank also offers bond products, such as corporate bonds, state treasury bonds, and ETF - Exchange Traded Found Bonds. As alternative investments BZ WBK has derivatives in its offer for wealthy clients, among others futures, options and currency options ${ }^{5}$. As part of non-banking activities for affluent BZ WBK provides tax advisory services which is the responsibility of the specialized consulting company Cirdo Taxand. In terms of cooperation the client is

\footnotetext{
${ }^{5}$ Investment Navigator, BZ WBK bank information materials.

Nawigator Inwestycyjny, Materiały informacyjne banku BZ WBK.
} 
provided with advice and services related among other the asset succession. Platinuma and gold cards available as part of the private banking segment enable the use of insurance services and the Concierge service. This service provides clients with assistance in organizing travel or buying tickets for cultural events. As part of the Priority Pass customers have access to over 700 VIP airport points in over 400 cities all over the world ${ }^{6}$.

In terms of private banking services, mBank offers a personal account - "private banking account" and the service "Private Concierge mBank." The customer who has a personal account is entitled to constant care of the private banking \& wealth management team. The mBank Private Concierge service includes business meetings, parties or travel, it also offers the possibility to rent a private bodyguard, translator or detective. The holder of a private banking account is entitled to the following payment cards ${ }^{7},{ }^{8}$ :

- Visa Classic Private Banking Card,

- World Elite MasterCard Credit Card,

- Visa Platinum PB Credit Card,

- Miles \& More Credit Card.

In addition mBank offers its clients asset management services through individual strategies and model strategies. The team of advisors places and manages the client's investment portfolio based on the power of attorney granted. Individual strategies are prepared on the basis of personalized needs and investment expectations of the service recipient and they are adjusted in terms of the asset class, fees and the place of capital allocation. In order for the client to use the individual strategy, he must have a minimum of PLN 5,000,000 in the bank. As part of the model strategies, mBank offers 6 strategies with different risk levels. Five of them have a benchmark set by advisors, one is an absolute return strategy. Funds of absolute return do not have a specific benchmark, and their allocation in equity instruments may vary from $0 \%$ to $100 \%$ - depending on the market situation ${ }^{9}$. Private investment consulting is another mBank service. It consists in fact providing the client with the most profitable cash allocation possibilities. Investment portfolios are built in this case through strategic capital allocation, diversification between different asset classes and active portfolio management. Investment advice is intended for clients who have not less than PLN 4000000. As part of the investment, mBank also has over 700 investment funds in its offer. These are funds: Polish, foreign, open and closed. Another service is assistance in the so-called property succession. It consists in securing and transferring the descendants' property in a determined manner. Assistance in intergenerational transfer consists of three stages. The first one comes down to a succession and legal-tax audit. The next stage is the implementation stage, involving the reconciliation of the succession plan and the transformation of the

\footnotetext{
${ }^{6}$ Credit cards. Karty kredytowe, https://pb.bzwbk.pl/finansowanie-premium.html, data dostępu: [22.06.2018].

${ }^{7}$ Private banking account, Konto private banking, https://www.mbank.pl/private-banking/uslugibankowe/konto/, data dostępu: [23.06.2018].

${ }^{8}$ Juszczyk S., Żak T., The evolution of payment cards, [in:] Zarządzanie Finansami i Rachunkowość, Warsaw University of Life Sciences in Warsaw, No. 3, Warsaw 2014. Ewolucja kart płatniczych, [w:] Zarządzanie Finansami i Rachunkowość, Szkoła Główna Gospodarstwa Wiejskiego w Warszawie, nr 3, Warszawa 2014. ${ }^{9}$ Asset management, https://www.mbank.pl/private-banking/wealth-management/asset-managment//, data dostępu: [23.06.2018].
} 
company. The last stage is a post-implementation stage assuming current tax and legal consultancy as well as analysis of the client's financial condition ${ }^{10}$.

The private banking segment of ING Bank Śląski has been operating on the Polish market since 2005. It's more important services in this field are directed to clients who want to multiply their accumulated capital. The bank's clients can deposit their funds using asset management assistance, investment consultancy, direct investment or savings accounts. As part of asset management ING offers portfolio investments consisting of 7 investment strategies, which are insurance capital funds with various investment risk levels. In the case of investment consulting the client obtains a personalized investment recommendation based on the client's risk appetite and the analysis of his needs. In the case of direct investments the client may carry them out through a brokerage account maintained by the ING Brokerage Office. In order to save cash the service buyer has at his disposal savings accounts and term deposits whose interest rates are determined in an individualized way. What's more private banking clients of ING Bank Śląski are entitled to a dedicated service a premium account and a platinum credit card. As in the case of term deposits the prices of credit products are determined on an individual basis. The clients of the wealth management segment are also entitled to wealth consulting services including: legal advice, educational consulting and art advisory which comes down to investment advice in the field of art. As part of legal advice the client gains information on, among other things, tax optimization and assistance in asset succession. Educational consulting relies in practice on the organization of language camps for children of clients and consultancy in the selection of studies. Customers of wealth management also have the opportunity to make investments using closed-end investment funds and specially created structured products ${ }^{11}$. As can be seen from the offers of the analyzed banks, the range of private banking services is quite wide. Table 4 presents financial products that have enjoyed or are the most popular among private banking offers of the surveyed banks.

Representatives of the analyzed banks emphasized that since the crisis, private banking customers have been reluctant to invest their funds into shares, as individual investors would like to protect their portfolio value or to gain stable and moderate growth with little risk. When asked about the most popular financial products 5 years ago e.g in 2013, private banking client advisors said that it was closed-end investment funds. Only the PKO BP advisers pointed out that the most popular financial products were bond funds at that time. The main difference between open investment funds and closed-end investment funds is their construction. Assets of closed-end investment funds are divided into investment certificates, which may be listed on stock exchanges. The number of participants in closed investment funds is limited by the terms of issue. Usually the minimum amount that the customer has to spend on investment in closedend investment funds is 40000 euro which is why most of the analyzed banks do not offer this investment solution in the retail segment ${ }^{12}$. In 2016 bond funds enjoyed the

\footnotetext{
${ }^{10}$ Succession, Sukcesja, https://www.mbank.pl/private-banking/wealth-management/transfer-miedzypokolenio wy/, data dostępu: [23.06.2018].

${ }^{11}$ Zakres usług, https://www.ingbank.pl/private-and-wealth/zakres-uslug/, data dostępu: [23.06.2018]; an interview questionnaire with a consultant from ING Bank Śląski. kwestionariusz wywiadu przeprowadzony z doradcą ING Banku Śląskiego.

${ }^{12}$ K. Jajuga, T. Jajuga, Inwestycje. Instrumenty finansowe..., s. 36.
} 
highest popularity among investment products at PKO BP. They are usually invested in Treasury bonds, municipal bonds and money market instruments. These funds are intended for clients who do not accept high investment risk and want to invest their money for a longer period. Also advisers to private banking clients of ING Bank Śląski pointed out that the most popular product at that time was a moderate risk fund ie $\mathrm{NN}$ Global Corporate Debt. The fund invests at least two-thirds of its assets in high-yield foreign bonds. According to mBank representatives closed investment funds were the most popular in both 2016 and 2013.

Table 4. Financial products enjoying the greatest popularity

\begin{tabular}{|c|c|c|}
\hline $\begin{array}{l}\text { Banks } \\
\text { Banki }\end{array}$ & $\begin{array}{l}\text { Years } \\
\text { Lata }\end{array}$ & $\begin{array}{l}\text { Financial product } \\
\text { Produkt finansowy }\end{array}$ \\
\hline \multirow{3}{*}{ PKO Bank Polski } & 2018 & $\begin{array}{l}\text { Treasury bonds } \\
\text { obligacje Skarbu Państwa }\end{array}$ \\
\hline & 2016 & $\begin{array}{l}\text { bond funds } \\
\text { fundusze obligacyjne }\end{array}$ \\
\hline & 2013 & $\begin{array}{l}\text { bond funds } \\
\text { fundusze obligacyjne }\end{array}$ \\
\hline \multirow{3}{*}{$\begin{array}{c}\text { Bank Polska Kasa } \\
\text { Opieki }\end{array}$} & 2018 & $\begin{array}{l}\text { negotiated deposits, structured products, } \\
\text { ETF (Exchange Traded Funds) } \\
\text { lokaty negocjowane, produkty strukturyzowane, ETF }\end{array}$ \\
\hline & 2016 & - \\
\hline & 2013 & $\begin{array}{l}\text { investment closed funds } \\
\text { fundusze inwestycyjne zamknięte }\end{array}$ \\
\hline \multirow{3}{*}{ Bank Zachodni WBK } & 2018 & $\begin{array}{l}\text { funds with lower risk, negotiated deposits } \\
\text { fundusze o mniejszym ryzyku, lokaty negocjowane }\end{array}$ \\
\hline & 2016 & - \\
\hline & 2013 & $\begin{array}{l}\text { investment closed funds } \\
\text { fundusze inwestycyjne zamknięte }\end{array}$ \\
\hline \multirow{3}{*}{ mBank } & 2018 & $\begin{array}{l}\text { cash funds with the lowest risk } \\
\text { fundusze pieniężne } \mathrm{z} \text { najmniejszym ryzykiem }\end{array}$ \\
\hline & 2016 & $\begin{array}{l}\text { investment closed funds } \\
\text { fundusze inwestycyjne zamknięte }\end{array}$ \\
\hline & 2013 & $\begin{array}{l}\text { investment closed funds } \\
\text { fundusze inwestycyjne zamknięte }\end{array}$ \\
\hline \multirow{3}{*}{ ING Bank Śląski } & 2018 & $\begin{array}{l}\text { cash funds with the lowest risk, ETF (Exchange Traded Funds) } \\
\text { fundusze pieniężne } \mathrm{z} \text { najmniejszym ryzykiem, ETF }\end{array}$ \\
\hline & 2016 & $\begin{array}{l}\text { investment funds with moderate risk } \\
\text { fundusze inwestycyjne o umiarkowanym ryzyku }\end{array}$ \\
\hline & 2013 & $\begin{array}{l}\text { investment closed funds } \\
\text { fundusze inwestycyjne zamknięte }\end{array}$ \\
\hline
\end{tabular}

Source: Own research.

On the Polish market in the private banking segment we can see the greatest interest in open investment funds with the lowest investment risk. These are usually cash or bond funds. Financial products that are most popular both in 2013 and 2016 are closed-end investment funds or open-end investment funds with moderate risk. Clients willingly choose this investment solution having the trust of experienced specialists and investment advisors who are building an investment portfolio and also because they want to diversify their portfolio and achieve profit from investments. It can be concluded that low-risk financial products enjoy the high popularity among private banking clients of 
the largest banks in Poland in 2018. The opinions of advisors on banking services in the private banking segment which will probably enjoy the highest popularity until 2020 are presented in table 5 .

Table 5. Opinions of private banking advisors regarding predictions as to the most popular banking services until 2020

\begin{tabular}{|c|l|}
\hline $\begin{array}{c}\text { Banks } \\
\text { Bank }\end{array}$ & \multicolumn{1}{c|}{$\begin{array}{c}\text { Banking service } \\
\text { Usługa bankowa }\end{array}$} \\
\hline PKO Bank Polski & $\begin{array}{l}\text { investment consulting, professional portfolio construction } \\
\text { doradztwo inwestycyjne, profesjonalna budowa portfela }\end{array}$ \\
\hline Bank Polska Kasa Opieki & $\begin{array}{l}\text { investment consulting based on the best global standards } \\
\text { doradztwo inwestycyjne oparte o najlepsze światowe standardy }\end{array}$ \\
\hline Bank Zachodni WBK & $\begin{array}{l}\text { investment consulting (wide) } \\
\text { doradztwo inwestycyjne (szerokie) }\end{array}$ \\
\hline mBank & $\begin{array}{l}\text { investment consulting (wide) } \\
\text { doradztwo inwestycyjne (szerokie) }\end{array}$ \\
\hline ING Bank Śląski & $\begin{array}{l}\text { only the necessary range of investment advisory services } \\
\text { tylko niezbędny zakres usług doradztwa inwestycyjnego }\end{array}$ \\
\hline
\end{tabular}

Source: Own research.

Bank advisers agreed that in the next years the most popular service provided under private banking will be probably the investment consulting. This service is the core of banking operations of commercial banks in the field of private banking. Legal and tax consultancy services, concierge or educational consulting are not the primary activities of banks. They are an addition to investment services provided under private banking and according to advisors they will not be more popular than investment consulting in the coming years. Most advisers pointed out that in the future the banks will compete for a wealthy client with smaller financial institutions for example with investment boutiques and brokerage houses. Also the digitization of banking services may bring less demand for personal meetings with a client adviser.

Table 6. The number of customers in the framework of private banking in the analyzed banks

\begin{tabular}{|c|c|}
\hline $\begin{array}{c}\text { Banks } \\
\text { Banki }\end{array}$ & $\begin{array}{c}\text { Number of clients (about) } \\
\text { Liczba klientów (ok.) }\end{array}$ \\
\hline PKO Bank Polski & 3000 \\
\hline Bank Polska Kasa Opieki & 10000 \\
\hline Bank Zachodni WBK & 3000 \\
\hline mBank & $4500-5000$ \\
\hline ING Bank Śląski & $\begin{array}{c}\text { refusal to answer } \\
\text { odmowa odpowiedzi }\end{array}$ \\
\hline
\end{tabular}

Source: Own research.

The clients of the private banking segment constitute a significant group among individual clients of the analyzed banks. Although their number is incomparably smaller than the number of customers from the retail and personal banking segment trading in assets of wealthier clients is very profitable for banks. This is due to the high profitability and strategic nature of private banking in Poland. 
Among the analyzed commercial banks the most clients in the private banking segment ie approx. 10000 people currently serves Bank Pekao SA. In 2005 there were around 6800 customers in this bank, although the admission criteria were only PLN 500 thousand of assets. In 12 years the number of clients has increased by about $50 \%$. The second place in terms of the number of private banking customers has mBank with the number of 4.5-5 thousand customers. PKO BP and BZ WBK service a total of about 6 000 affluent clients. In the case of ING Bank Śląski, the data regarding the number of served clients was not disclosed. It can therefore be assumed that the total number of private banking clients in Poland amounts to approximately $25-30$ thousand and is constantly growing which also indicates the growing importance of this banking area in Poland.

\section{Conclusions}

The conducted research is not a comprehensive analysis of private banking in Poland. They were based only on five largest banks in Poland. Therefore the obtained results cannot be a generalization for the entire Polish banking sector in Poland. Nevertheless based on the research the following conclusions were formulated.

1. Financial products with the lowest investment risk enjoy the highest popularity among private banking clients of the largest banks in Poland in 2018. Customers include cash and bond investment funds as well as negotiable term deposits for these products. The reason for the high popularity of these financial products may be the age among the analyzed group of clients and having an above-average value of assets. Private banking clients are predominantly over 50, who do not show a high propensity to investment risk. They have accumulated above-average values of capital in the past, therefore they do not care about the aggressive multiplication of cash but rather on their protection of value and prefer possible low-risk construction of the investment portfolio.

2. Investment consulting is the essence of commercial banks in Poland in the field of private banking. Non-bank services offered by commercial banks such as legal and tax consultancy, educational consulting or concierge services do not constitute the core activity of private banking offer but are its addition. The research suggest that in the next 2-3 years investment consultancy will still be an important service within private banking.

3. The research results suggest that in the coming years commercial banks providing private banking services will compete for a wealthy client with smaller financial institutions. The banking sector will also continue to digitize banking services and products. For this reason it is necessity of changing the business model into a model adapted to digital transformation. This is one of the very important challenges facing the Polish private banking segment as well as the entire banking sector.

\section{Bibliografia}

Asset management, https://www.mbank.pl/private-banking/wealth-management/assetmanagment $/$.

Bankowość codzienna, https://www.pekao.com.pl/private/nasza_oferta/bankowosc_codzienna/.

Dziawgo L., Private banking: bankowość dla zamożnych klientów, Wolters Kluwer, Kraków 2006. 
Gancewski K., Zmiany jakościowe private bankingu w Polsce. Warszawa, 2018 r.

Jajuga K., Jajuga T., Inwestycje. Instrumenty finansowe, aktywa niefinansowe, ryzyko finansowe, inżynieria finansowa, Wydawnictwo Naukowe PWN, Warszawa 2006.

Juszczyk S., Żak T., Ewolucja kart płatniczych, [w:] Zarządzanie Finansami i Rachunkowość, Szkoła Główna Gospodarstwa Wiejskiego w Warszawie, nr 3, Warszawa 2014.

Karty kredytowe, https://pb.bzwbk.pl/finansowanie-premium.html, data dostępu: [22.06.2018].

Konto private banking, https://www.mbank.pl/private-banking/uslugi-bankowe/konto/.

Lokaty Strukturyzowane, https://www.bzwbk.pl/oszczednosci-i-inwestycje/oszczednosci-i-

inwestycje/.

Macierzyński M. , Pekao S.A.: Udowodnimy, że zastugujemy na miano lidera,

https://www.bankier.pl

Materiały informacyjne banku BZ WBK dostępne w placówce oddziału.

Mazurek J., Kultura, sztuka, wino i klimat, http://www.idg.pl/artykuly/55277.htm.

Nawigator Inwestycyjny, Materiały informacyjne banku BZ WBK dostępne w placówce oddziału.

NN (L) Globalny Długu Korporacyjnego kat. A, Kluczowe informacje dla inwestorów, 15.02.2018

Oferta, http://www.bankowoscprywatna.pkobp.pl/oferta/, data dostępu: [22.06.2018].

Rozwiązania finansowe, https://www.pekao.com.pl/private/nasza_oferta/rozwiazania_finansowe/.

Sukcesja, https://www.mbank.pl/private-banking/wealth-management/transfer-miedzypokolenio wy/.

World Wealth Report 2017; Capgemini: 2017, s. 3.

Zakres usług, https://www.ingbank.pl/private-and-wealth/zakres-uslug/.

\section{Streszczenie}

Celem badań było rozpoznanie i ocena zmian private bankingu w Polsce. W toku badań ustalono między innymi, że produkty finansowe o najmniejszym ryzyku cieszą się obecnie największą popularnością wśród klientów private bankingu badanych banków. Na podstawie wyników badań ustalono również, że najbardziej popularną usługą, świadczoną w ramach private bankingu $\mathrm{w}$ najbliższych 2 latach będzie prawdopodobnie doradztwo inwestycyjne. Usługi pozabankowe takie jak doradztwo prawno-podatkowe, doradztwo edukacyjne czy usługi concierge będą w dalszym ciagu dodatkiem oferty w ramach private bankingu w Polsce.

Słowa kluczowe: zamożność, private banking, wealth management, grupa HNWI

\section{$\underline{\text { Informacja o autorach }}$}

Prof. dr hab. Sławomir Juszczyk

Warsaw University of Life Sciences

Faculty of Economic Sciences,

Department of Finance

e-mail: slawomir juszczyk@sggw.pl

ORCID: 0000-0003-3790-6247

\section{Karol Gancewski}

mBank 